\title{
Agriculture, Forestry and Water Resources Management: A Panacea for Sustainable Development in Nigeria
}

\author{
Greg Ekpung Edame, Ph.D. \\ Department of Economics, Faculty of Social Sciences, University of Calabar, \\ P.M.B.1115, Calabar, Cross River State, Nigeria. \\ Email: gregedame@yahoo.com
}

Effiong, Charles Efefiom

Department of Economics, School of Social Sciences, Cross River State College of Education, Akamkpa-Nigeria Email: dodosky01@yahoo.com

\section{Eba, Maxwell -Borjor Ackuk}

Department of History and International Studies, University of Calaba, PMB. 1115, Calabar, Cross River State, Nigeria

Doi:10.5901/ajis.2014.v3n4p373

Email : raremaxxy@yahoo.com

Abstract

Given the central role of agriculture and the unprecedented changes in climate anticipated over the next few decades, the need for sustainable development cannot be over emphasized. Unfortunately, several human activities aimed at economic growth and development has put man and the environment in a precarious position. Such activities include bush fallow, inappropriate technologies, overpopulation, overgrazing, deforestation without adequate reforestation and profligate exploitation of mineral resources. The obvious result of these activities is the increasing inability of agricultural, forestry and water resources to enhance sustainability in the process of economic growth and development. This study therefore adopted an econometric approach to investigate the negative influence natural resource exploitation and utilization pose on Nigeria's economic development. However, the paper believes that, in as much as technological advancement and innovation is a sine qua non for economic growth and development in nearly all the sectors of the Nigerian economy, such advancement must be approach with caution because of its associated implications on environment, natural resources and most importantly sustainability of our economic growth and development process. Hence, appropriate management via the adoption of a more pragmatic and environmental friendly approaches such as renewable energy sources mostly in the power sector as well as zero tolerance for gas flaring.

Keywords: Agriculture, Forestry, Water Resources, Sustainable Development.

\section{Introduction}

Sustainability expands the concept of development by recognizing the ecological limits imposed on achieving a given set of development objectives. According to Ress $(1989,3)$ "Sustainable Development is positive socioeconomic change that does not undermine the ecological and social systems upon which communities and social systems are dependent"

The central role played by the agricultural sector (including forestry and water resources ) in economic growth and development cannot be over emphasized rather it's patient to note that such resources due to its renewability in nature are significant for sustainable development. The resulting report, our common future (1987), posited sustainable development to development that meets the needs of present without compromising the ability of future generations to meet their own needs. Suffice us to add that sustainable development emerged as a new development paradigm and has been adopted by the international community as an overarching development goal since the United Nations Conference on Environment and Development (UNCED) held at Rio de janeiro in 1992. At the world summit on sustainable development in Johannesburg in 2002, government adopted the Johannesburg plan of implementation (JPOI) which called upon countries to take immediate steps to make progress in the formulation and elaboration of the National Sustainable Development Strategy (NSDS), and begin their implementation by 2005. "In Nigeria, agriculture was a long history of being the main stay of the economy until when petroleum was discovered in the 70s, subsequently exploited and then came the distortion created by the fall in world oil price.

With a population of 167 million (NBS, 2011), Nigeria is the most populous country in Africa, with a GDP second 
only to South Africa's. Yet, following several years of military rule and poor economic mismanagement, Nigeria experienced a prolong period of economic stagnation, rising poverty levels, and the decline of its public institutions in spite of her abundant human and natural resources.

\subsection{Statement of Problem}

The importance of sustainability of production system is becoming a major concern of researchers and policy makers in both developed and developing countries. Sustainability represents the last step in a long evolution that economic development must consider both the protection of national resource and the maintenance of environmental quality (Batie, 1987). Water and forest resources play a crucial role in food production regionally and worldwide. On the one hand, more than $80 \%$ of global agricultural land is rain-fed; in these regions, crop productivity depends solely on sufficient precipitation to meet evaporative demand and associated soil moisture distribution (FAO, 2003). Where these variables are limited by climate, such as in arid and semi-arid regions in the tropics and sub-tropics, as well as in Mediterraneantype regions in Europe, Australia and South America, agricultural production is very vulnerable to climate change (FAO, 2003). On the other hand, global food production depends on water only in the form of precipitation but also, and critically so, in the form of available water resources for irrigation. Indeed, irrigated land, representing a mere $18 \%$ of global agricultural land, produces 1 billion tons of grain annually, or about half the world's total supply; thus is because irrigation crops yield on average 2-3 times more than their rain-fed counterparts (FAO,2003).

The demise of key ecosystems of the developing world include managers (35\% either lost or degraded), coral reefs (30 percent), and tropical forests (30 per cent) (FAO, 2001, 2003; Valiela et al., 2001; Millennium Eco-system Assessment, 2005; UNEP,2006). Nigeria has pursued with vigor the exploitation of her natural endowment with the purpose of maintaining its sustenance. Given the current international debt issues and associated problems; it has become increasingly difficult to generate enough resources required for sustainable socioeconomic growth without executing increased pressure on local resources for producing more food for local consumption and other agricultural products for export, in order to gain access to capital for further development.

Development had been conventionally based on the use of natural resources since the vast population is rural and agricultural production is the main occupation. However, if land is expected to continue to produce, this and other resource base must at least be maintained, rehabilitated and properly managed. Fortunately, however, government and some non-government agencies, for instance the Nigeria conservation society are getting involved in creating an awareness of the need to use judiciously, and thus preserve the Nigerian environment (West Africa 1990). Although preservation and other measure so far taken are steps in the right direction, they do not appear to be adequate, particularly in ensuring a widespread knowledge, especially among farmers of the relationship between the use of the environmental resources and its effects on agricultural and sustainable development, hence, this paper is to highlight the need for sustainable economic growth and development.

\subsection{Objective of the study}

Nigeria, a country blessed with vast natural resources has witnessed crisis that bothered on resource management and adequate utilization of revenue. Therefore, this study highlights the relevance of natural resource management on sustainable development. Specifically, the objectives are:

(i) To examine the influence of technology on the Nigerian economy.

(ii) To assess how gas flaring affect the economy.

(iii) To examine the existing relationship between agricultural output and economic growth.

\subsection{Research Hypothesis}

The following hypothesis was tested to satisfy the broad objectives of this study:

(i) Ho Technological advantage has a negative impact in the Nigerian economy.

(ii) Ho: Gas flaring has a negative influence on economic growth of Nigeria.

(iii) Ho: There is no significant relationship between agricultural output and economic growth in Nigeria.

\subsection{Significance of the study}

The vast human and natural resources of Nigeria continued to be a source of concern to researchers, policy makers and 
international communities. Such concerns arise due to the untold hardship the exploitation of some these resources has brought on an average Nigerian. Environmental degradation, spillage, extinction of some fauna and flora as well as the inability maintain the carrying capacity due mismanagement of our natural resources. However, this study aims at enlightening stakeholders, policy makers, and the host communities on the dangers of water contamination, deforestation and the general effect of unregulated exploitation of our natural resources.

Renewable energy has been the issue dominating the world affairs and as such this study serve as a vehicle aids the diversification of our economy to ensure sustainability via the adoption of more environmental friendly technology and institution of policy and programmes that will facilitate and enhanced adequate management of our natural resources efficiently.

\section{Literature Review}

\subsection{Nature and Status of Forest Resources in Nigeria}

The estimated forest area in Africa is $16 \%$ of the global forest area (FAO, 2007). The percentage of the total land area covered by forest is $12.2 \%$, i.e about 110,890 ha, 36,500 of which covers forest plantations. These have decreased yearly between 1996 and 2000 by a negative factor of $1.5 \%$. According to $F A O(2007)$, the annual change rate for forest in Nigeria, between 1990 and 2000, was about -2.7\%, while between 2000 and 2007, it decreased by 3.35 (Table1). Nigeria has the worst deforestation rate of primary forest from 2000 to 2005 among some selected low income countries (Table 2).

Table1: Forest Area of Nigeria and Rate of change

\begin{tabular}{|c|c|c|c|c|c|c|}
\hline $\begin{array}{c}\text { Total Forest area } \\
(1000 \mathrm{ha})\end{array}$ & $\begin{array}{c}\text { \% change in land } \\
\text { area }\end{array}$ & $\begin{array}{c}\text { Forest } \\
\text { plantation }\end{array}$ & $\begin{array}{c}\text { Rate of change } \\
(1990-2000)\end{array}$ & $\%$ & $\begin{array}{c}\text { rate of change } \\
(2000-2005)\end{array}$ & $\%$ \\
\hline 11.089 & 12.2 & 3.65 & -410 & - & -410 & - \\
\hline
\end{tabular}

Source: FAO, 2007.

Table 2: Deforestation Rate of primary forest for selected low income countries (2000-2005).

\begin{tabular}{l|l}
\multicolumn{1}{c|}{ Countries } & $\%$ \\
\hline Nigeria & 55.7 \\
Vietnam & 54.5 \\
Cambodia & 29.4 \\
Sri lanka & 15.2 \\
Malawi & 14.9 \\
Indonesia & 12.9 \\
North Korea & 9.3 \\
Nepal & 9.1 \\
Panama & 6.7 \\
Guatemala & 6.4
\end{tabular}

Source: Mongabay, 2005

Table 3: Forest growing stock in Nigeria: Biomass and Carbon

\begin{tabular}{|c|c|c|c|c|c|}
\hline Growing stock & Biomass & & $\begin{array}{c}\text { Quantity of carbon } \\
\text { in biomass }\end{array}$ & \\
\hline Per ha $\left(\mathrm{m}^{3} / \mathrm{ha}\right)$ & Total (Million $\left.\mathrm{m}^{3}\right)$ & per ha (ton/ha) & Total (million ton) & Per ha (ton/ha) & Total tonnage (million) \\
\hline 125.0 & 1386 & 225.9 & 2.804 & 126 & 1401.0 \\
\hline
\end{tabular}

Source; FAO,2007

\subsubsection{Deforestation}

Deforestation due to oil activities has been severe in Nigeria since the late 1960s especially in the Niger Delta region in 
which crude oil deposits are found of Nigeria's 92 million hectares of land area, forest occupies a third, and 2 million hectares of this remain in reserve protecting watersheds, controlling soil erosion, recycling minerals and nutrients, influencing climate, and serving as habitation of game species (Ubom, 2000). Also wildlife is a viable source of meat supply for human consumption. It may be interesting to note that more than 15 per cent of animal protein consumption in rural communities is obtained from wildlife. For instance, the estimated demand for bush meat as it is called in Nigeria would grow from 198, 872 long tons in 1974 to 216,703 long tons in 1985, where as the deficits or gaps in supply and demand would rise from 46, 170 long tons in 1974 to 46, 388 long tons in 1985" (Olayide, 1981 forecasted). He based his forecast on rapid rate of deforestation.

Wildlife also constitutes a source of foreign exchange earnings. According to Olayide (1981:114) "...substantial exports demand for wildlife products such as reptile skins, furs, animal oils, ivory, caged birds etc. of tropical forest origin continues to grow rapidly' He pointed out that between 1960 and 1970, average annual export of reptile and fur skins was 63.84 per cent, which attracted average annual revenue of $\mathrm{N} 0.55 \mathrm{~m}$.

Identification of oil in any area calls for diligent geographical and geological surveys, which involve cutting of traverses, seismic operation, identification of rock formation and their characteristics (okoji, 2000). These activities deflorate the forest, and thus contribute significantly to killing and slaving away of game species. For instance, at Elekpa and Dikki in Rivers state, and Egbeno Angalabiri in Bayelsa state, not less than hectares of forest have been pulled down at flow station and drilling sites (okoji, ibid). According to Olayide (1981:114) and Usoro 91998), there is a pressing need for the abatement, if not reversal, of these activities, and the like, for without which, the 2 million hectares of Nigeria's forest reserve will disappear before the year 2050.

\subsubsection{Urbanization and Economic Peformance}

Nigeria is predominantly agricultural economy, the bulk of its population lives in rural area engaging in agriculture for livelihood. Nigeria's development is therefore primarily tied to the development of agriculture (Richards, 1987). The emergence of oil has broken this tie since 1970s. The huge oil revenues have been greatly used in urban construction and expansion of urban informal sector which according to Richards (1987) " has hardly unambiguously favoured agriculture", as it engendered" rural-to-urban migration". This usually reduces the supply of prime age males who had been involved in agriculture. Thus, a vacuum which cannot be filled by elders, younger or female farmers for some technical and/or social reasons have been created. Rural-to-urban migration causes localized labour shortages and wage increases, which often push farmers into cost gulp. This practicatically causes farm profits to fall, and makes farm maintenance/management harder. Thus farmers may be forced to quit farm whereas urban population (that is, number of urban consumers) increase. This induces rapid expansion in food imports.

In the 1960s, oil was discovered in the Niger River delta of Nigeria. In 1973 and again in 1979, the world price of oil exploded. These oil booms transformed the Nigerian economy to that in fairly short order the petroleum sector dominated. By the mid-1970s, oil accounted for over 90\% of exports (Alan Gelb and Associates, p.250) and was responsible for 70 to 80 per cent of government revenues (Alan Gelb and Associates, p.240). The rising price of oil allowed rapid increases in federal government spending on transportation, communications, and infrastructure and on education. The government also launched a massive dine to encourage universal primary education (Alan Gelb and Associates, p.243). Estimates indicate that Nigeria's capital stock grew at an average of 14\% per year between 1973 and 1980 (Xavier Sala-i-martins and Arvind sub bramanian, p.14).

The acquisition of additional physical and human capital made possible by the oil booms of the 1970's should have helped the Nigerian economy more onto a path of sustained growth and development. However, the Nigerian economy has progress unevenly at best. Table 2 provides some basic indicates on material and social welfare to support this.

Table 2: Basic Development Indicators

\begin{tabular}{|l|c|c|c|c|}
\hline & 1970 & 1980 & 1990 & Latest years (in parenthesis) \\
\hline PPP, GDP per Capital & $\$ 255.96$ & $\$ 893.92$ & $\$ 983.04$ & $\$ 826.47(2000)$ \\
\hline Life Expectancy at birth & & 46 & 52 & $45(2002)$ \\
\hline Male Adult Literacy rate & & 59 & & $74(2002)$ \\
\hline Female Adult Literacy rate & & 38 & 39 & $59(2002)$ \\
\hline Gross primary School enrollment rate & 37 & 104 & 75 & $96(2002)$ \\
\hline Gross Secondary School enrollment rate & 27 & 22 & 19 & - \\
\hline
\end{tabular}

Source: World Bank and Penn world Table 6.1 
GDP per capital has clearly increased since 1970. However, in 2002 it has lower than in 1990, indicating that Nigeria has not been able to sustain increases in average living standards. In addition, life expectancy at birth, an indicator of health, has been virtually unchanged since 1980. Further, efforts to increase access to education have had improved. Primary school enrollment has increase since 1970, but not consistently. Secondary school enrollment has actually fallen since 1970.

As first approximation, the increased resources especially physically capital, did not translate into sustained increases in living standards because these resources where not productivity used. A crude growth accounting exercise provides support for this. As table 3 illustrates, 87\% of the growth of GDP between 1965 and 2002 was due to the growth of inputs (labour and capital). Only about $13 \%$ was due to growth of total factor productivity (TFP), which is growth that cannot be explained by increases in the amounts of labour and capital, and therefore largely results from how productivity labour and capital are employed.

Table 3: Demostration Of Growth Of Nigerian Gdp (1965-2002)

\begin{tabular}{|l|c|c|}
\hline \multicolumn{1}{|c|}{ Growth of GDP due to: } & Percentage points & Share of GDP Growth \\
\hline Growth of labour & 1.62 & $44.6 \%$ \\
\hline Growth of physical capital & 1.54 & $42.4 \%$ \\
\hline Residual (Growth of TFP) & 0.47 & $12.9 \%$ \\
\hline Growth of GDP & 3.63 & $100.0 \%$ \\
\hline
\end{tabular}

Based on data from the World Bank and authors.

A similar decomposition of the 6.9\% GDP growth rate during the period 1965 to 1980 , which includes the 1970's oil boom, shows that TFP was actually negative. Digging deeper, one can argue that oil itself is the roof of the problem. In fact, Nigeria illustrates quite clearly the above-listed three reasons why resource-rich economics experiences difficulty translating their natural wealth into sustained growth.

\subsubsection{Gas Flaring}

About 2 million barrels oil and an average of 1.9 million cubic meters $\left(\mathrm{m}^{3}\right)$ of associated gas are produced in Nigeria daily $9 C B N, 2001)$. Of this about 80 per cent of gas produced is flared while about 20 per cent is utilized as reflected in Table1. (See Apendix I)

For example, in 1970, 8039 millionm ${ }^{3}$ of utilized while 7957 million $\mathrm{m}^{3}$ was flared. In 1977, of 21924 million $\mathrm{m}^{3}$ gas produced, only 973 million on $\mathrm{m}^{3}$ was utilized while 20952 million $\mathrm{m}^{3}$ was flared. In 1990, whereas 28163 million $\mathrm{m}^{3}$ was produced, 21820 million $\mathrm{m}^{3}$ was flared, while only 6343 million $\mathrm{m}^{3}$ was utilized. In 2000 , of 36537.5 million $\mathrm{m}^{3}$ gas

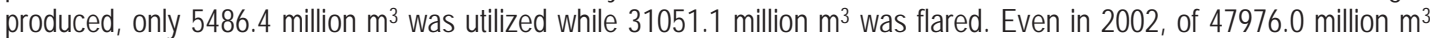
gas produced, 21772.6 million $\mathrm{m}^{3}$ was flared while 26203.4 million $\mathrm{m}^{3}$ was utilized.

Flaring apart from being economic waste, is hazardous to human, animal and plant health. Gases emitted into the atmosphere during flaring combine freely with other gases and may produce concentrations of gases like nitrogen (iv) oxide $\left(\mathrm{NO}_{2}\right)$, Sulphur (iv) Oxide $\left(\mathrm{SO}_{2}\right)$, hydrogen sulphide $\left(\mathrm{H}_{2} \mathrm{~S}\right)$, Carbon (iv) Oxide $\left(\mathrm{CO}_{2}\right)$, Carbon monoxide ( $\mathrm{Co}$ ), and some volatile organic. Compounds which may be fatal to both animal and plant lives. Also, gas faring contributes significantly to high radiant energy (light and heat), and as it is well known, climate plays an invaluable role in agricultural output, and thus, causes soil moisture to evaporate more rapidly. This results in loss of soil nutrients, and subsequent poor crop yield. The high radiant energy may alter the process of photosynthesis as well. It also increases water temperature, thus, increasing the toxic effect of water pollutants which is very detrimental to aquatic live (Dorf, 1978:426).

\subsubsection{Oil Spill}

Oil spill is a frequent major harzard in Nigeria especially in the Niger Delta region. It occurs in many ways. Oil pipes sometimes burst and spill on land and water, likewise platforms and exploratory wells. Spills from oil tankers are rampant. These occurs during oil loading, discharging and bunkering. Oil spill also occurs through sabotage. Instances of oil spill in Nigeria are various. Between 1970-1983, offshore and onshore oil spillage amounted to 17,113,536 barrels, and of major spills from shell operations world-wide, 40 per cent occurs in Nigeria (NNPC, 2000). Oil spills affects both aquatic and terrestrial lives. For instance, spill at Eleme, Rumuekpe and Bonu in River state, and out-jeremi in Delta state posed a great hindrance to agricultural development (Okoji, 2000) as "aquatic and terrestrial vegetations run over by flowing crude 
became jet black, and farm crops completely destroyed", "Marine lives e.g. Fishes suffer from gill clog", (Ubom, 20000. Table 2 shows the distribution of oil spill in Nigeria between 1991 and 2000.

Table 2: Distribution of oil spill in Nigeria Between 1991 and 2000

\begin{tabular}{|c|c|c|c|}
\hline Year & Number of Cases & Volume of oil spilled (barrels) & Operation(s) involved \\
\hline 1991 & 58 & 200,000 & Shell, Texaco, Mobil \\
\hline 1992 & N.A & N.A & N.A \\
\hline 1993 & N.A & N.A & N.A \\
\hline 1994 & N.A & 360,000 & Shell, Chevron, Mobil \\
\hline 1995 & 59 & 36,000 & NACO, ELF, Agip \\
\hline 1996 & 40 & 78,000 & Shell, Mobil, NACO \\
\hline 1997 & 32 & 60,000 & Shell, Agip, Mobil, NACO \\
\hline 1998 & 16 & 24,000 & Shell \\
\hline 1999 & 36 & 30,000 & Shell, Texaco, Mobil \\
\hline 2000 & 47 &
\end{tabular}

Source: Nigeria National Petroleum Company Annual Reports, 2000.

The surface of farmland overrun by crude oil becomes clogged. This reduces the rate of air penetration into the soil. Equally, Micro-organisms such as Azotobacter, Nitrobacter, Nitrosomonas, whose activities in nitrogen cycle are imperative are destroyed. According to ihejiamaizu (1999) and Ubom (2000), oil spillage has a serious negative effect on agricultural production as seeds; stems etc, planted in oil-spilled area absorb the oil and get destroyed.

\subsubsection{Water Resource Challenges}

The availability of water is a key factor in the restructuring of forest and grassland systems as the climate warms climate change is known to alter the likelihood of increased wildlife size and frequency, while also inducing stress in tress, which indirectly exacerbates the effects of these disturbances. Many forest ecosystems in the tropics, high latitudes and high altitudes are becoming increasingly susceptible to drought and associated changes in fire, pests and diseases. It has been estimated that up to $40 \%$ of the Amazonian forest could be affected by even slight decrease in precipitation (Rowell and more, 2000). Global estimates of the number of people living in areas with water stress differ significantly between studies (Vorosmarty et al., 2000; Alcamo et al; 2003 a, b, 2007; Oki et al., 2003; Arnell, 2004).

Nevertheless, climate change is only one of many factors that influence future water stress; demographic, socioeconomic and technological changes possible play more important roles at most time horizons and in most regions. In the 2050s, differences in the population projections of the four IPCC SRES Scenarios would have a greater impact on the number of people living in water-stressed river basins than the differences in the climate scenarios (Arnell,2004). Fisher etal.(2006) and Arnell et al. (2004) also projected increases in water stress (Measured as the ratio of irrigation withdrawals to renewable water resources) in the Middle East and South-east Asia. Recent regional studies have likewise underlined critical climate change/water dynamics in key irrigated areas, such as northern Africa (increased irrigation requirements; Abou-hadid et al; 2003) and china (decreased requirements; Tao et at., 2003a).

The number of people living in water stressed river basins would increase significantly (Table 3.3). If water stress is assessed not only as a function of population and climate change but also of changing water use, the importance of nonclimatic drivers (income, water-use efficiency, water productivity, and industrial production) increases (Alcamo et al, 2007). Income growth sometimes has a larger impact than population growth on increasing water use and water stress (when expressed as the water withdrawal; water resources ratio).

Table 3.3: Impact of population growth and climate change on the number of people living in water-stressed river basins (defined as per capita renewable water resources of less than 1,000 $3 / \mathrm{yr}$ ) around 2050.

Estimated population in water-stressed river basins in the year 2050 (billions)

\begin{tabular}{|c|c|c|}
\hline & Arnell(2004) & Alcamo et al.(2007) \\
\hline 1995:Baseline & 1.4 & 1.6 \\
\hline 2050: $\mathrm{A}_{2}$ emissions scenario & $4.4-5.7$ & $6.4-6.9$ \\
\hline $2050: B_{2}$ emissions & $2.8-4.0$ & $4.9-5.2$ \\
\hline
\end{tabular}

Source: Adopted from climate change and water, IPCC Technical paper VI 
However, water resources are a key vulnerability in Africa for household, agricultural and industrial uses. In shared river basins, regional co-operation protocols are needed to minimize both adverse impacts and the potential for conflicts. For instance, the surface area of Lake Chad varies from $20,000 \mathrm{~km}^{2}$ during the dry season to $50,000 \mathrm{~km}^{2}$ during the wet season. While precise boundaries have been established between Chad, Nigeria, Cameroon and Niger, sectors of these boundaries that are located in the rivers that drain into Lake Chad had never been determine, and additional complications arise as a result of both flooding and water recession. Growing water scarcity, increasing population, degradation of shared freshwater ecosystems and competing demands for shrinking natural resources distributed over such a huge area involving so many countries have the potential for creating bilateral and multilateral conflicts. In Nigeria, waste oil is often discharge by oil constructed from the base of their furnaces to nearby streams/rivers. This kills aquatic lives. For instance, the Warri refinery discharges its waste oil into Obiteho and Obetemidaka streams. In these streams and their tributaries many aquatic lives are destroyed (Okoji, 2000). As these streams and/or rivers flow through farmlands, and swamps, crops and vegetation get ruined.

\subsubsection{Empirical Literature}

In order to avoid the depletion of natural resources, thus reducing the growth and development propensity of nations, the need to use the most efficient production and extraction system is essential. The conservation of natural resources, however, entails a better knowledge of the limitations imposed by the natural and manmade environment as well as the need for ecological balance. Yudelman (1987) noted that the accelerating determination of the resource base in much of sub-Saharan Africa threatens to reduce production. This crisis is largely due to the rising pressure of human and livestock population on traditional shifting cultivation. The conservation on wetlands (Ramsar, 1971) considers that river basin or river catchments (the land area between the source and the mouth of a river including all of the lands that drain into the river) and coastal and marine systems influenced by catchment discharges are important geographical units for considering the management of wetlands and water sources. Emmanuel et al (1995) provided an overview of agricultural and forestry development in the Amazon basin, and presents and discusses the main land use systems as evident in the region. These are logging, shifting-cultivation and ranching. The issue of sustainability is addressed and current Amazonian land use is interpreted in light of ecological impacts and long-run viability. They also considered the ecological notion of criticality, endangerment, impoverishment and resilience. After addressing the threats to land us encroachment to the forest resource base, the paper identities sufficient conditions for regional ecosystem sustainability and considers desirable technological and policy oriented responses in this regard. They concluded with a call to future research on land use systems, noting, however, that the greatest challenges are the design of equitable government policy for the adoption of sustainable system.

By and large, tropical forests Constance to carbon cycles, patterns of climate and biodiversity. These ecosystems make up 40 per cent of the terrestrial stock of plant biomass, and they are extremely productive, yielding between 30 and 42 percent of the terrestrial total of net primary productivity (Whittaker and likens, 1973; Malingreau and Tuker, 1988)). It should come as no surprise then that tropical deforestation is implicated in processes discussion in this regards has focused on the controversy of $\mathrm{CO}_{2}$ envisions and accumulation in atmosphere 9Schneider, 1989).

Forest vegetation stores large quantities of carbon as biomass, and its exchanges of $\mathrm{CO}_{2}$ with the atmosphere are an order of magnitude greater than the contribution from human activities (Dickinson,1989; Houghton and Woodwell, 1989). On the other hand, deforestation releases between 1-6 billion tons of carbon each year, an amount that is about 30 percent of the flux associated with fossil fuel consumption (Houghton, 1995). Moreover, tropical forest exert an important influence on regional climate (Shilkla et al., 1990 ; Salati and Vose, 1992) and may contain up to two-thirds of the 10-15 million species existing in the world today (Williams,1989). Some deforestation is necessary for agricultural development, as was the case in many temperate countries during early phases of economic growth (Cronon, 1983; walker, 1994). Nevertheless, a sizeable component of the current rate of conversion is attributable to an excessive intrusion of the extensive margin of market agriculture into forestry land use and ling-fallow farming.

These intrusions have been associated with government actions such as the provision of subsides and infrastructures (Repetto and Gillis, 1988), with contractual failures between loggers and resources owners, including states (walker, 1987; walker and smith, 1993) and with the use of inappropriate farming technologies and systems (Janzen, 1973). Unekwe (2010) in a study "the impact of poverty on the sustainability of forests in Nigeria: Implication for sustainable forests and reduction in global warming" maintained that, one of the key resources in Nigeria that is fast increasing fast in it's non-sustainability status is the forest. He went further that forest is important in view of it role in economic development and trapping of $\mathrm{C}_{2}$ to show down the process of global warming. 
However, according to him, the rapid rate of deforestation has been linked with increase in prices of petroleum products, especially dual purpose kerosene and a correlation coefficient of 0.771 , significant at 5 per cent shows that poorer geopolitical regions tends to use more wood fuel to meet their domestic requirement. He believes that the enactment and enforcement of progressive forest laws, a participatory approach, as well as the encouragement of the practice of agro-forestry are also canvassed to sustain the forest resources and reduce Nigeria's meager contribution to climate change.

Forest litters and soil microbes, together constitute an important resource that makes forest fertile for arable farming in the tropics (Akachukwu, 2006). Also, the ecotourism value of the forest is a formidable tool for sustainable economic development in Nigeria (Adeyemo and Okosodo, 2005; Akachukwu,2005). Again, forests are an important, defense against the global climate change. Through the process of photosynthesis, forests produce life-giving oxygen and consume huge amounts of carbon-dioxide, the atmospheric chemical most responsible for global warming. By decreasing the amount of carbon-dioxide in the atmosphere, forests can reduce the effects of global warming (Mastrandra and Schneider, 2009).

In Nigeria, another factor responsible for the depletion of forests is the de-re-servation of forest reserves by the government for development purposes, without any care for replenishment or relocation to other areas. Over exploitation occasion by greed and illegal exploitation, to the extent that it outstrips regeneration, is also another threat to the sustainability of forest resources in the country. According to Akachukwu(2005), petroleum exploration, exploitation, and oil spillage are, together, destroying large areas of swamp forest in Nigeria. Depletion of soil and water resources, destruction of earths webs of life, loss of recreational potentials, and the reinforcement of climate problems, like climate change are some other impacts of unsustainable forest use (Wikipedia, 2010).

The pathetic state that the Nigerian forest was captured by stock (2008). According to him, the bulk of Nigeria's forest production is fuel wood, consumed either as wood or as charcoal. In 2006, fuel wood production was 62 million cubic meters (2.2 billion cubic feet), harvested mostly near dense urban areas. By constant, annual timber production mostly hardwoods, such as Mahogamy, Iroko, and Obeche-averaged 2 million cubic meters (71 million cubic feet), almost all from the tropical forest zone. Consequently, Nigeria, once a significant exporter of timber, is a net importer. Ongoing, rapid deforestation makes it unlikely that the situation will improve appreciably. The major causes of deforestation include corruption, overpopulation, urbanization, population growth, inequitable distribution of wealth and poverty 9wikipedia Encyclopedia, 2010). The united Nations Framework convention on climate change has stated that the over whelming cause of deforestation is agriculture. It stated that subsistence agriculture accounts for $48 \%$ of deforestation, while $32 \%$ of deforestation results from commercial agriculture. Wood fuel is said to account for $5 \%$.

According to Choji (2005), more than half of 9.6 million ha of rain forests in the south of Nigeria have been used to meet the demand for fuel wood in rural and urban neighborhoods. Compared with the costs of petroleum products, fuel wood is cheaper than any commercial fuel substitute and thus has, over the years, increases forest depletion (choji,2005), as this appears to decrease their expenditure on fuel to the detriment of the environment and the sustainability of the forest.

As at 2007, the types of fuel used in cooking in Nigeria are segregated as follows: Wood (74\%), electricity (0.7\%), gas (0.7\%), kerosene (24\%), and coal (1.6\%). Between 1996 and 2007, the amount of kerosene consume in the country decreased steadily (CBN, 2008) of course this decrease was informed by an increase in the prices of petroleum products (choji,2005), especially dual purpose kerosene, which is commonly used for domestic cooking. Increases in the prices of petroleum products have also worsened the poverty situation in the country (CBN, 2006). It is easy to agree with the fact that the amount of woods used would have to increase since it is the only accessible alternative. This paper however, is not interested in the increasing arguments concerning the causes of non-sustainability but to highlight the contributions of noted variables in the economic growth and development process of Nigeria. According to Unekwu (2010) forest is one of the resources in Nigeria that is fast increasing in its non-sustainability status while Cronon91983) and Walker (1994) believes that some deforestation is necessary for agricultural development. Therefore, it is pertinent to determine the impact of those critical variables affecting sustainability as well as their associated effects in the economic growth and development of Nigeria.

\section{Theoretical Framework}

The limits to growth model are based on its basic thesis that "the continued growth leads to infinite quantities that just do not fit into a finite world." Some of the basic thesis are analyzed below as;

(1) The future world population level, food production and industrial production will first grow exponentially, 
become increasingly unmanageable and their collapse during the $21^{\text {st }}$ century.

(2) The collapse follows because the world economy will reach its physical units in terms of non-renewable resources, agricultural land and the earth's capacity to absorb excessive pollution which are finite

The theory of natural resources' scarcity and its effect on growth and, partly, on the principles of natural resources conservation. The theory, which is credited to some classical economist like Malthus (1798), Ricardo (1821) and Mills (1963) holds the view that scarcity of natural resources would eventually lead to diminishing social and economic returns to human efforts and ultimately to stagnation, retardation and cessation socio-economic growth.

In economics, the Cobb-Douglas functional form of production functions is widely used to represent the relationship of an output to inputs. They considered a simplified view of the economy in which production output is determined by the amount of labour-invested and the amount of capital invested provided all the available factors of production are efficiently employed. The function they used to model production was of the form:

(1) $Y=A K^{b} L^{c}$

Where:

$Y=$ Output (it could be GDP or Industrial or Manufacturing output).

$A=$ State of technology or efficiency parameters

$\mathrm{K}=$ Capital employed

$\mathrm{L}=$ Labour employed

$b+c=1$ (displaying constant returns to scale-CRTS)

But today's production processes are characterized by increasing returns to scale (IRTS). In other words, it is to say that technology changing capabilities are characterized by IRTS. That being the case, the function in equation (1) can be modified to replaced the original factors (Labour and Capital) with factors that are noted to hinder sustainable development. This is basically done to ensure that:

(i) Factors or policies which stimulate accumulation of technology changing skills (embodied) are accounted for.

(ii) The efficiency in the use of factor of production associated with technology using skills is taken into account.

\section{Methodology}

In contrast to the approaches of previous studies, we employ an econometric approach to investigate the quantitative approach to relationship between real GDP which measures economic growth and population growth rate which measures environmental degradation via urbanization. Gas flaring measures impact of Petroleum exploration on the economy. Technology, forestry output and agricultural output are included as a result of their capacity to enhance sustainability. The available annual data which are secondary in nature were obtained from CBN publication (CBN statistical bulletin 2009) and data center spanning a period of 40 years (1970-2012). To facilitate a comparison with the findings of previous studies, the estimating model developed for this is based on the augmented production function. The real output growth equation is expressed as:

$\mathrm{Y}_{\mathrm{t}}=\mathrm{B}_{0}+\mathrm{B}_{\mathrm{i}} \mathrm{X}_{\mathrm{i}}+\mathrm{B}_{2} \mathrm{~K}_{\mathrm{t}}+\mathrm{B}_{3} \mathrm{Z}_{\mathrm{t}}+\mathrm{B}_{4} \mathrm{~T}_{\mathrm{t}}+\mathrm{B}_{5} \mathrm{~A}_{\mathrm{t}}+\mathrm{E}_{\mathrm{t}}$

Where, $Y_{t}$ is real output; $X_{t}$ is population growth $\mathrm{Kt}$ is gas flaring; $Z_{t}$ is Forestry output; it is a technology during; $A t$ is agricultural output and Et is a zero mean white-noise error term.

To assure appropriate model specification and to reduce the possibility of arriving at misleading results, we next examine the time series properties of the variables by analyzing their order of integration through unit root tests. This will help to determine whether the subsequent estimation should use the level or first difference of each of the time series. The basic empirical methodology used in this research relates to the Co integration and error correction Modeling (ECM) approach that has become very popular in recent applied Econometrics. See, for example, Harris (1995) and Stock and Watson (2003). The light linkage between Co integration and ECM stems from the Granger representation theorem. According to this theorem, two or more integrated time series that are co integrated have an error correction representation and two or more time series that are error correcting are co integrated (Engle and Granger,1987). In short, the two concepts are isomorphic as each implies the other.

The concept of co integration and ECM are introduced to avoid spurious regression (Lauriden, 1998). While theory of co integration was developed by Granger(1983) and Granger and Weiss(1983), ECM was introduced by Phillip (1954) and was first used in economics by Sagan (1964). It have been observed that since the application of ECM by Davidson et al (1978), ECM have been playing an important role in the dynamics of both short-run (change) and long-run (levels) adjustment processes. The cointegration and ECM takes account of the dynamics adjustment to steady state targets by including in the short-term dynamics a measure of how far from equilibrium the variables were at the start of the period. 
Granger (1986) demonstrates that the dynamic relation among cointegrated variables can be represented by an ECM. This thas gained a great deal of popularity in recent applied econometrics, since it integrates long-run relationships among the variables with short run dynamics necessary to restore equilibrium when departures occur. This approach by Granger (1986) ranks very paramount in this paper. The need for the use of cointegration and Error Correction modeling analyses was due to data instability caused by instability in Nigeria's economic terrain; with frequent policy changes, political-economic disruptions, etc. therefore, the need for data differencing when the time series data is non-stationary for meaningful economic results becomes necessary. Also other purposes were to examine the time series properties of the data, overcome the problem of spurious correlation often associated with non-stationary time series data, and generate long run relationships simultaneously (Engle and Granger, 1987).

It is important to note that the usual starting point of ECM modeling is to assess the order of integration of both the dependent and independent variables in the model. The order of integration ascertained the number of times a variable will be differentiated to arrive at stationary, i.e. I (0).

\section{Empirical Results and Discussion}

\subsection{Unit Root Order of Integration Results}

Table 4.1.1 Unit Root Test

\begin{tabular}{|l|c|c|c|c|l|}
\hline \multicolumn{1}{|c|}{ Variables } & Statistics & \multicolumn{2}{|c|}{ ADF Tests Critical values } & \multicolumn{1}{c|}{ Order of integration } \\
\hline & & $1 \%$ & $5 \%$ & $10 \%$ & \\
\hline \multirow{2}{*}{ D(RGDP) } & 1.5961 & -3.6105 & -2.9391 & -2.6079 & Non-stationary in level I(0) \\
& -5.4418 & -3.6156 & -2.9411 & -2.60191 & Stationary at First difference I(I) \\
\hline D(POP) & -4.5417 & -3.6105 & -2.9389 & -2.6079 & Stationary in level I(0) \\
\hline D (GASF) & -4.7309 & -3.6105 & -2.9389 & -2.6079 & Stationary in Level I(0) \\
\hline \multirow{2}{*}{ D(FOUT) } & -0.9215 & -3.6104 & -2.9389 & -2.6079 & Non-stationary in Level I(0) \\
& -6.6495 & -3.6156 & -2.9411 & -2.6090 & Stationary at first difference I(I) \\
\hline \multirow{2}{*}{ D(AOUT) } & 2.1492 & -3.6104 & -2.9389 & -2.6079 & Non-Stationary in level I(0) \\
& -5.3085 & -3.6155 & -2.9411 & -2.6090 & Stationary at first difference I $(\mathrm{I})$ \\
\hline D(TECH) & 10.9544 & -2.6256 & -1.9496 & -1.6115 & Stationary in Level I $(0)$ \\
\hline
\end{tabular}

Key: ADF =Augmented Dickey Fuller

$\mathrm{I}(1)=$ Stationary at first difference

$I(0)=$ Non- stationary in level

RGDP = Real Gross Domestic product

$\mathrm{POP}=$ Population growth rate

GASF $=$ Gas flaring

FOUT $=$ Forestry output

AOUT = Agricultural output

$\mathrm{ECH}=$ Technology

Stationary Test: For Co integration analysis, it is important to the unit check the unit roots at the outset to ascertain whether modeled variables are I( 0 ) at levels I(1) or I(0) at difference. Tables 4.1.1presents the results of the unit root test using the Augmented Dickey Fuller (ADF). The test was applied to each variables over the period of 1970 to 2009 with a time trend at the variables level and at their difference. The test results are compared against the Mackinnon (1996) onesided P-values or critical values for the rejection of the null hypothesis of no unit root. The results shows that out of the five independent variables adopted, three were stationary in levels I(0) (POP,GASF and TECH) at 1\%,5\% and $10 \%$ level of significance while the other two FOUT and AOUT were stationary $\mathrm{I}(0)$ at first difference. This indicates that the variables are I(1) and any attempt to specify the dynamic function of the variable in level will be inappropriate and may lead to problems of spurious regression in line with Mesike at al (2010). The econometric results of the model in that level of series will not be ideal for policy making (Yusuf and Falusi, 1999) and at such; the results cannot be used for prediction in the long-run.

\section{Cointegration Test}

Given the ADF results presented below, there is the justification for a cointegration test to determine whether or not 
cointegration relationships exist between Real GDP and population growth rate, gas flaring, Forestry output, Agric output and technology. Using Engle and Granger(1987)assumption which states that "two or more integrated time series that are cointegrated have an error correction representation, and two or more time series that are error correcting are cointegrated". Granger (1986) also demonstrated that the dynamic relation among cointegrated variables can be represented by an ECM, the approached was adopted to test for cointegration among the variables in this study. After testing the residuals, the results revealed that there is no cointegration (long-run relationship) among the variables. Though the coefficient had the expected negative sign, it is not significant explaining the changes in RGDP. It therefore means that, the relationship existing among the variables can best be explain in the short-run. This is because the tstatistics of -0.7769 is less than the critical values of $(-2.6256,-1.9496$ and -1.6115$)$ at $1 \%, 5 \%$ and $10 \%$ levels of significance respectively.

Table 4.1.2 ECM Test for Co-integration

Unit Root Test for Ecm

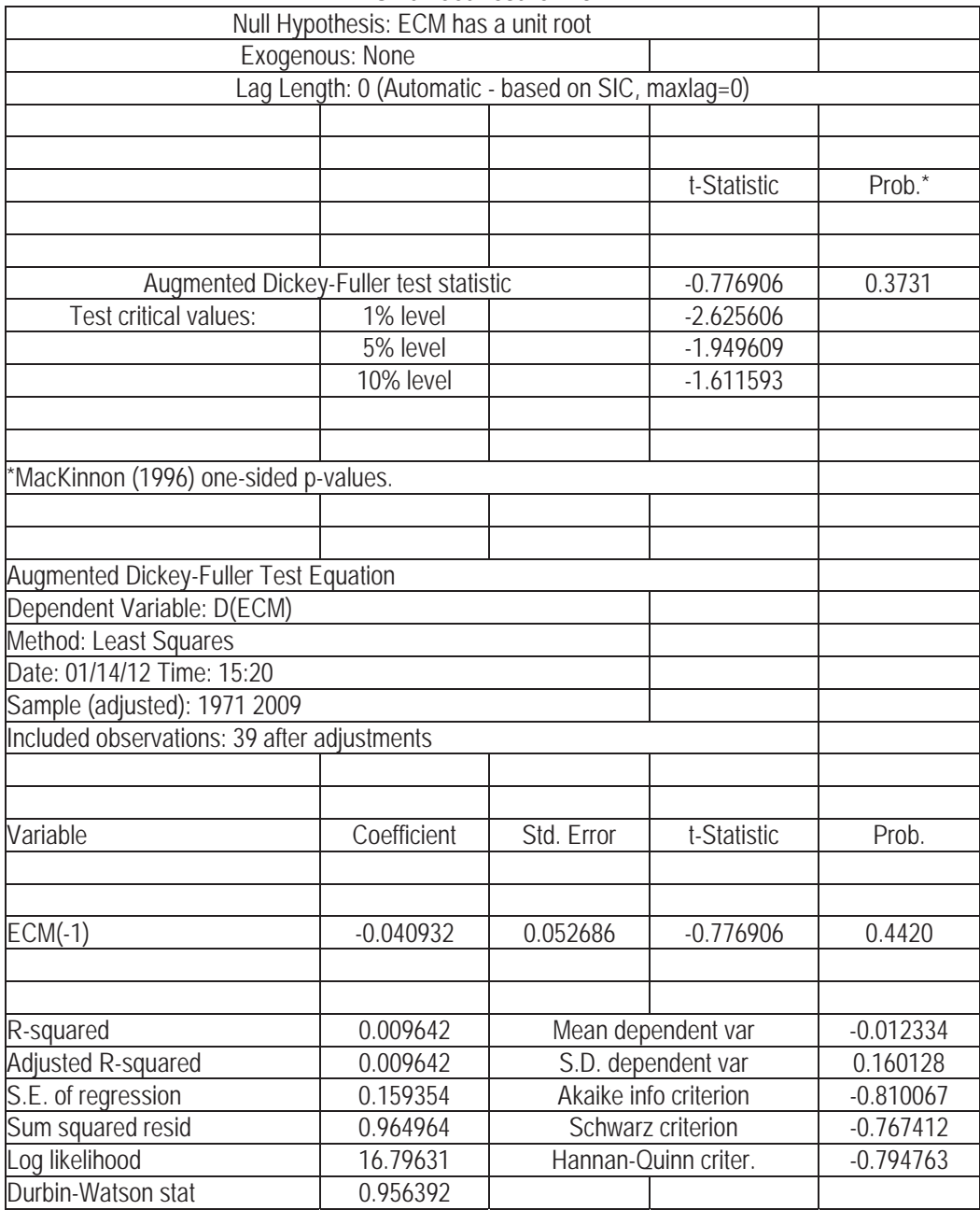


Table 4.1.3 Regression Result and Analysis

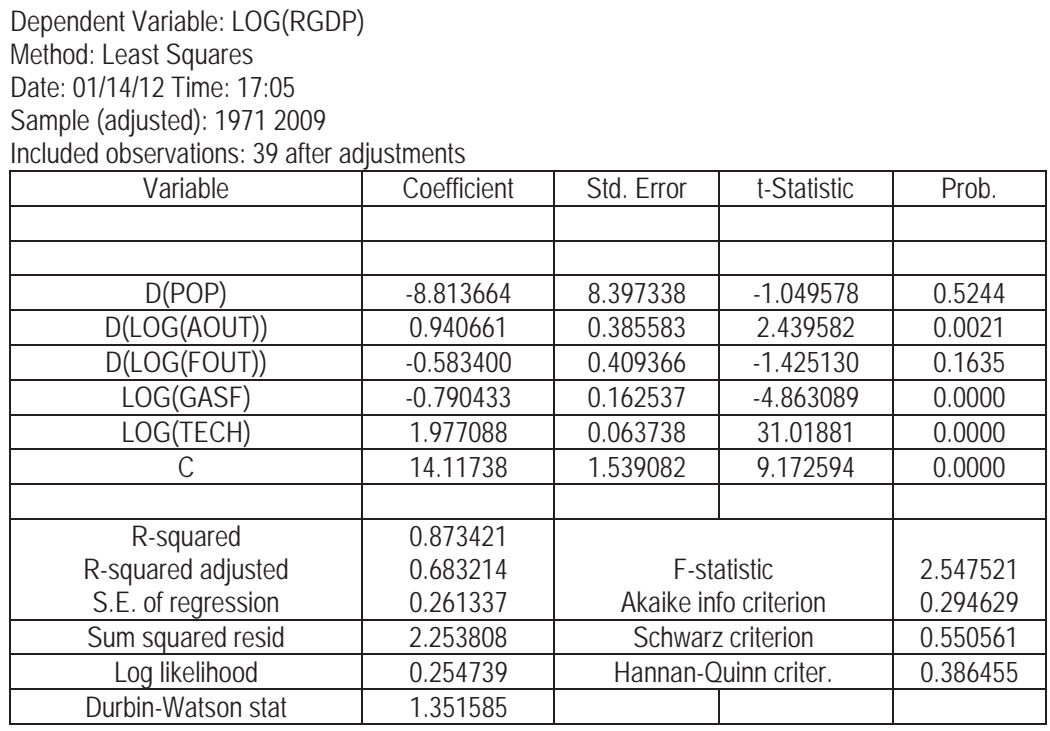

Since there is no long-run relationship among the variable, the changes among them can only be explained in the shortrun (Engle and Granger, 1987). Hence, the least square method of analysis was adopted to analyze their relationships.

According to table 4.1.3, all the variables except FOUT conform to economic theory. This is because D (LOG (FOUT)) instead of increasing real output, tends to reduce it with a coefficient of 0.58 . The highest contributor to increased in real output is TECH followed by AOUT while POP has the highest negative effect on the economic as observed in the results presented above. From the variables used, AOUT and TECH were statistically significant at both $5 \%$ and $10 \%$. However, GASF which reduces economic growth was also significant at both $5 \%$ and $10 \%$ levels of significance. This shows that GASF at present posed the greatest hindrance to sustainable growth in Nigeria. The other two variables (POP and FOUT) even though they deterred sustainable growth, the effect was not statistically significant. The Durbin-Watson result of 1.352 depicts that; we can't conclusively affirm the existence or non existence of Autocorrelation in the result. Nevertheless, our adjusted R-squared shows that the model explained about $68.32 \%$ of the total variation in our dependent variable leaving $31.68 \%$ for factors not captured in the model. The statistical significant of F-statistics means that our model can be relied upon for forecasting the factors responsible for sustainable economic growth and the factors that hinders economic growth in Nigeria.

\section{Conclusion}

This paper aimed at highlighting the relevance of natural resource management to sustainable economic growth in Nigeria. Economic theory suggests that agricultural output, forestry output, improved technology are key growth ingredient. However, Nigeria is highly dependent on petroleum export, this export even though it lead to an increase in revenue, it associated effects is detrimental to sustainable development and has lead to rural-urban migration thereby fostering the neglect of the agricultural sector. After, testing for unit root to determine whether the variables are stationary, the results from the co integration test via ECM method of Engle and Granger reveals that long-run relationship does not exist among the variables. This means that the variable wander away from themselves without a long-run relationship, hence, any level of economic growth witness in Nigeria is not inclusive. This outcome supports the views of Yudelman (1987), Ress $(1989,3)$ and (CBN, 2006) that any economic growth which benefits only a strata/sector of the economy is meaningless and may not sustained the economy.

However, our empirical results unambiguously suggest that only TECH and AOUT are key growth ingredient in Nigeria. GASF happens to be the major factor hindering sustainable growth in Nigeria. By and large, natural resource management in Nigeria need not be over-emphasized because the current effect is only explained in the short-run, the long-run effect might be worst. 


\section{Recommendations}

Findings from the results of this study suggest the importance of the Nigerian government to intensify policy measures that will enhance increased agricultural output as well as initiate programmes that check deforestation. The policy on zero gas flaring must be strengthen and implemented to it later if sustainability must be achieved within the short time possible.

Countries with high population are noted for advantages that can transform their economy, therefore the government needs to initiate programmes and policies that will transform the lives of the citizens and add value to the economy in the long-run. Developing countries requires economic growth, and mostly such growth is achievable through technological innovation. Moreso, the high unemployment rate in Nigeria need technology to effect change, however, such innovation requires caution because there is always a price to pay for a meaningful change to occur.

\section{References}

Abou-Hadid, A. F.; Mougou, R. ; Mokssit A: and Iglesias A. (2003). Assessment of impacts, Adaptation, and vulnerability to climate change in North Africa: Food Production and Water Resources. AIACC AF90 semi-Annual Progress Report, 37pp.

Adeyemo, A. I. and Okosodo, F. (2005) Ecotourism for economic empowerment in Nigeria. Proceedings of the $31^{\text {st }}$ Annual Conference of the Forestry Association of Nigeria held at University of Agriculture Makurdi. November 20-25,2005,228-239.

Akachukwu, A.E. (2005) Disappearing Forests, the consequences and challenges of Sustainable Development in Nigeria. Proceedings of the $31^{\text {st }}$ Annual Conference of the Forestry Association of Nigeria held at University of Agriculture Makurdi. November, 20-25,2005, 49-57.

Alcamo, J.; Doll, P.; Hen richs, F; lehner, B; Rosch, T. and Siebert, S. (2003a) Development and testing of the water GAP2 global model of water use and availability Hydrol. Sci. Jn 48,317-338.

-(2003b) Global estimates of water withdrawals and availability under current and future "business-as-usual" conditions. Hydrol. Sci. J., 48,337-348

Alcamo, J.; Florke, M. and Marker, M. (2007) Future long-term changes in global water resources driven by socio-economic and climatic change. Hydrol.Sci. J., 52,247-275

Arnell, N.W. (2004) Climate Change and global water Resources: SRES envisions and socio-economic scenarios. Global Environment change, $14,31-52$.

Arnell, N.W.; Livermore, M.J.L.; Kovates, S.; Levy, P.E; Nicholls, R.; parry, M.L and Gaffin, S.R. (2004) Climate and Socio-economic Scenarios for global-scale climate impacts assessments: Characterizing the SRES story lines. Global Environ change., 14.3-20.

Batie, Sandra S. (1987). "Sustainable Development: Challenges to the profession of Agricultural Economics" AJAE 70(5)

Bates, B.C.,Z.W. Kundzewicz, S.WU and J.P.Palutikof, Eds (2008): Climate change and water. Technical paper of the Intergovernmental panel on climate change, IPCC Secretariat, Geneva, 210pp.

CBN (2006) Annual Statement of Account, Central Bank of Nigeria, Abuja, Nigeria

Central Bank of Nigeria (CBN), Annual Report and statement of Accounts, December 2001, 61.

Central Bank of Nigeria (2001), statistical Bulletin, vol, 12, December , 174.

Central Bank of Nigeria (2005), statistical Bulletin, vol, 16, December.

CBN(2005) CBO Annual Statement of Account, Ganki, Abuja, Nigeria

Choji, I.D. (2005). The Impact of Government Policies on Fuel Prices on the Environment. International Journal of Business and Common Market Studies , 3(2); 94-100.

Cronon, W(1983), Changes in the Land: Indians, Colonists, and the Ecology of new England. New York: Hill and Wang.

Davidson, J. E. H; Hendry, D. F.; srba, F.; and yeo J. S. (1978) Econometric modeling of the aggregate time-series relationship between consumers' expenditure and income in the United Kingdom. Economic Journal, 88;661-692.

Dickey, D. A and Filler, W. A. (1979) Distribution of the estimators for autoregressive time series with Unit root. Journal of the American Statistical Association, 74:427-431.

Dickinson, R.E.(1989),Amazon deforestation: predicting Climate effects Nature, XLI: 343-344.

Engle, R. F and C.W.J. Granjer (1987). "Cointegration and Error-correction Representation, Estimation, and Testing," Econometrica, 55, $251-276$.

FAO (2007) The State of the World's Forest. Rome: Food and Agricultural Organization

FAO (Food and Agricultural Organization), 2003 World Agriculture Towards 2015/2030.http//www.fao.org/documents/show-cdr.asp?urlfile=idocrep/004/y3557e/y3357e00.htm.

Fischer, G.; Tubiello, F.N.; Van Velthuizen and Wiberg (2006) Climate change impacts on irrigation water requirements: global and regional effects of mitigation, 1990-2080. Tech. forecasting soc. Ch., 74 doi: 10.1016 /;techfore. 2006.05.021.

Gelb, Alan and Associates (1988). Oil windfalls: Blessing or curse? New York: Oxford University press for the World Bank.

Granger, C. W. J (1986) Developments in the study of cointegrated economic variables. Oxford Bulletin of Economics and Statistics, 48; $213-228$.

Granger, C. W. J and Weiss, A. A.(1983) Time Series Analysis of Error-correcting models. In: Studies in Econometrics, Time Series, and Multivariate Statistics. New York : Academic press, pp. 255-278.

Granger, C. W. j. (1983) Forecasting White noise. In; A zellner (Ed.): Applied Time Series Analysis of Economic Data. Washington, DC: Bureau of the census, pp. 308-314.

Harris, R. (1995), Using Cointegration Analysis in Econometric Modeling, London: Prentice-Hall publishers.

Houghton, R.A. (1995) Balancing the Global Carbon Cycle with terrestrial eco systems. In: R. Zepp (Editor) . The Role of Non-Living Organic Matter in the Earth's Carbon Cycle, New York NY. Wiley 
Houghton, R.A. and Woodwell, G.M. (1989) Global Climatic Change. Sci. Am., 260 (4): 36-44.

Ihejiamaizu, E. (1999) "Socio-economic Impact of Oil Industry Activities on Nigerian Environment: The Case of Eboeha Gas Plant and Brass Terminal", International Journal of Tropical Environment,Calabar: University of Calabar press, 36-49.

Janzen, D.H. (1973) Tropical agro-ecosystems: These habitats are misunderstood by the temperate zones, mismanaged by the tropics, science, 182:1212-1219.

Lauriden, J. (1998). Spatial cointegration Analysis in Econometric Modelling. Department of statistics and Demo-graphy, Odense University. Compusvey 55 DK-5230 odense M. Available online at www.ou.dk/rrvf/staldem/lauriden.html (Accessed 14/7/2010.

Malingreau, J. and Tucker, C. J. (1988) Large Scale deforestation in the Southeastern Amazon Basin of Brazil. Ambio, 17:49-55.

Malthus, T. R. (1798) An Essay on the principles of population As Affects the future improvement of society, London: Methuen \& Co. Itd,.

Mastrandrea, M. and Schneider, S. H. (2008) "Global warming" Microsoft (R) Encrta (R) 2009 [DVD]. Redmond, WA: Microsoft corporation.

Mesike, C. S; Okoh, R. N. and Inoni, O. E. (2010) Supply Response of Rwbba farmers in Nigeria: An Application of vector Error correction model. Agricultural Journal, J (3) : 146-150.

Millennium Ecosystem Assessment (2005a) Ecosystems and Human well-being: Volume 2-scenarios. Washington DC: Island Press,515pp.

Mills, J. S 91963) Collected works (Toronto University press).

Mongabay, C. 92005) Nigeria has worst Deforestation Rate: FAO Revised Figures.

NBS. (2011). Annual abstracts of statistics. Abuja: National Bureau of statistics.

Nigeria National Petroleum Corporation (2000), Annual Reports, Abuja, NNPC.

Oki, T.; Agata, Y.; Kanae, S.; Samhashi, T. and Musiake, K. (2003) Global water resources assessment under climate change in 2050 using TRIP. Water Resources: Systems water Availability and Global change, S.W.Franks, G. Boschil, M. Kumagai, K. Musiake and D. Rosebjerg, (Eds)., IAHS Publication, 124-133.

Okoji, N.A. (2000) "Petroleum Oil and the Niger-Delta Environment" , International Journal of Environmental studies, OPA, N.V., Malaysia, Vol. $57,713-723$.

Olayide, S.O. et al (1981) Elements of Rural Economics, Ibadan: University Ibadan press publishing House.

Phillips, A. W. H(1984) Stabilization policy in a closed economy. Economic Journal, 64:290-333.

Repetto, R. and Gilliz, M. (Editors) 1988. Public Policies and the Misuse of Forest Resources Cambridge :Cambridge University Press.

Ress, W. (1989) "Sustainable Development: Myths and Realities" in Environment and Economic partners for the future. Conference_proceeding, Winnipeg, Government of Manitoba.

Ricardo, D. (1821). On the principles of political Economy and Taxation, London: (3'rd edition)

Richards, A. (1987) "Oil booms and Agricultural Development", in Michael Wath(ed), State, Oil and Agriculture, Berkeley Institute of International Studies, 85-105

Rowell, A. and Moore, P.F. (2000) Global Review of forest fires. WWF/IUCN, Gland,66Pp. http//www.iucn.org/themes/fcp/publications /files/global-review-forest-fires.pdf.

Salati, E. and Vose, R. (1992) Awazone Basin: A system in equilibrium. Science 1225:129-138.

Sargan, J. D(1964) Wages and prices in the United Kingdom: A study in Econometrics methodology. In ; P. E. Hart, G. Milla and J. N. Whiltaker (Eds.)! Econometric Analysis for National Economic Planning, London: Butter worths, pp.-54.

Schneider, S.H(1989) The greenhouse effect: Science and Policy, Science 243:771-781.

Shukla, J.; Nobre, C.A. and Sellers, P. (1990) Amazon deforestation and climate change. Science, 247:1322-1325.

Stock, J. H. and M. W. Watson (2003) Introduction to Econometrics, Boston: Addison wesky publishers.

Stock, R. (2008) Nigeria. Microsoft (R) Encarta (R) 2009 [DVD]. Redmond, WA: Microsoft corporation.

Toa, F.; Yokozawa, M.; Hayashi, Y. and Lin, E. (2003a) Changes in agricultural water demands and soil masture in china over the half-century and their effects on agricultural production. Agri. Forest Metcorol., 118; 251-261

Ubom, M.R.(2000) "Exploitation and conservation of Natural Resources" in Ubom(ed), History and Philosophy of Science, Kaduna: Abam Publishing Company.pp31-38.

Unekwu Onuehe (2010). Impact of poverty on the sustain ability of forest in Nigeria: Implication for sustainable forests and Reduction in global warming Journal of sustainable Development in Africa (vol. 12, No.6, 2010)

United Nations Environmental programme, (2006).

Usoro, E.J.(1998), The Threatened Earth: A Synthesis of Ecological sustainability. Ikot-Ekpene: Usako press Ltd.

Vorosmarty, C.j; Grenn, P. J; Salisbury, J. and hammers, R. B (2000) Global water resources: Vulnerability from climate change and population growth. Science, 289, 284-288.

Walker, R.T (1987) Land use transition and deforestation in developing countries. Goegr, Anal., 19(1): 18-30.

Walker, R.T (1994) Deforestation and Economic development, Cam. J. Reg. Sci., 16(3): 481-497.

Walker, R.T and T.E. Smith (1993) Tropical deforestation and forest management under the system of concession logging: a decision-theoretic analysis .J.Reg. sci., 33(3) : 387-419.

Whittaker, R.H and hikens, G.E.(1973) Carbon in the biota-hi; G.M. woodwell and E.V. pelan (Editors).Carbon and the Biosphere. U.S. Atonne Energy Commissioner.Symposium series 30, National Technical Information service, spring field, VA,Pp. 281-302.

Wikipedia Encyclopedia. (2010). Sustainability of Forest Resources and Climate Change. Retrieved from www.fao.org/globalwarming on the 5th of April, 2010.

William, M.(1989) Deforestation: Plast and Present. Prog. Hum. Geogr., 13:176-208.

World Commission on Environment and Development (1987), Food 2000: Global Policies for Sustainable Agriculture. Zed Book LTD London.

Yudelman, Montage (1987) Prospects for Agricultural Development in Sub-Saharan Africa. Occasional paper (Winrock International Institute for Agricultural Development) (April) Little Rock, ArKansas.

Yusuf, S. A and Falusi, A . O (1999) Incidence Analysis of the effect of Liberalization trade and Exchange rate policies on cocoa in Nigeria: An ECM approach. Rural Economic Development 13:3-14. 